\title{
AVAILABILITY AND UTILIZATION OF AMINO ACIDS FOR GROWING PIGS
}

\author{
EDWARD S. BATTERHAM
}

NSW Agriculture, Wollongbar Agricultural Institute, Wollongbar, New South Wales 2477, Australia

\section{CONTENTS}

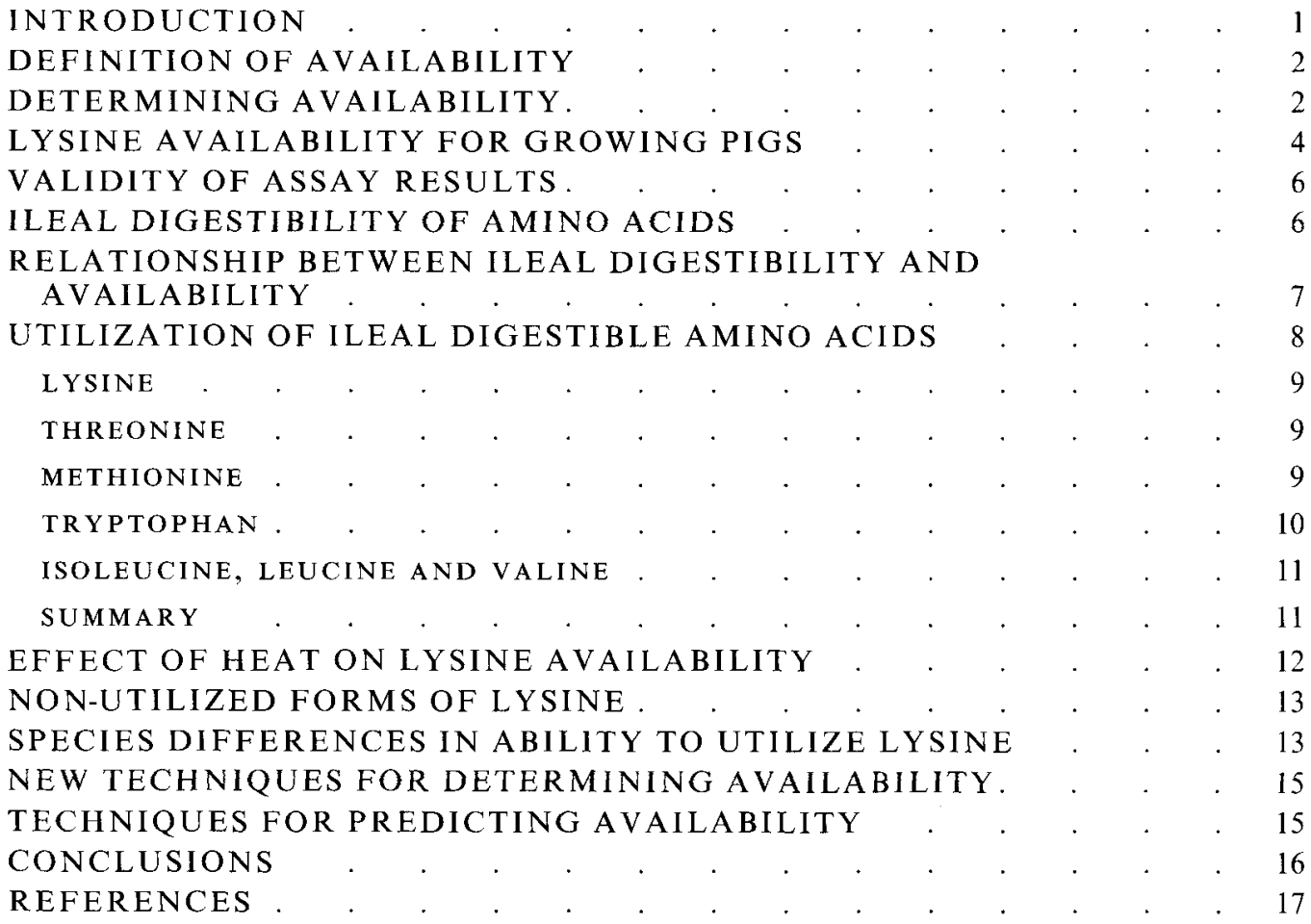

\section{INTRODUCTION}

A considerable amount of research has been undertaken to develop rapid techniques for determining the availability of amino acids. However, little progress has been made in recent years. This in part reflects the difficulty of the field, a decline in research activity and a focus of attention on digestive physiology rather than on amino acid utilization. As a result, the development of a rapid assay to predict amino acid availability remains as elusive as ever.

This review concentrates on the assessment of availability with growth assays, and the relationship between the ileal digestibility and availability of amino acids. The potential of new techniques for assessing availability is examined. 


\section{DEFINITION OF AVAILABILITY}

There are considerable differences in what the term 'availability' means to nutritionists. For some, digestibility and availability are synonymous. This arises from the belief that if a nutrient is digested, it is available for use. Whilst this might apply in some areas of nutrition, it is inappropriate in the amino acid field, where it is possible for amino acids to be absorbed in forms that may be inefficiently utilized. For amino acids, the definition needs to include a provision for utilization. Thus for amino acids, the Little Oxford Dictionary definition of 'capable of being used' is appropriate, and can be expanded as follows - 'the proportion of the total amino acid that is digested and absorbed in a form suitable for protein synthesis.'

\section{DETERMINING AVAILABILITY}

If one accepts the above definition for 'availability' then it follows that availability can only be determined by techniques that measure the utilization of an amino acid when it is limiting in the diet. Also, availability can only be determined for one amino acid at a time. The most usual technique is a growth assay, where the response to increasing increments of the test amino acid in a protein is compared to the response to the standard free amino acid. Treatments are normally arranged in a statistical design called a slope-ratio assay (Fig. 1). In essence, one expresses the slope of the response to the diets containing test amino acid as a proportion of the slope of the response to the standard (free) amino acid. A number of inclusion points are necessary (at least three) to ensure that the response to the test amino acid is linear. The assumption is made that the slope of the response to the addition of the test amino acid is due to the availability of the test amino acid and is not influenced by other nutrients contributed by the protein source. In practice, this is a difficult condition to meet. There are, however, a number of statistical safeguards which can be used to try to ensure that the response is valid.

When designing an assay to measure amino acid availability there are a number of conditions that need to be addressed. These include the following.

(1) Ensuring that the pig's response is due to the test amino acid and is not influenced by other nutrients contributed by the test protein. In designing a basal diet, it is necessary to choose a diet that is deficient in the test amino acid, but adequate in all other nutrients so that an adequate, linear response to the standard amino acid is possible. The basal diet contains a non-protein energy source, which is replaced as the test protein is incorporated into the basal diet. The test protein is preferably incorporated into the basal diet to supply similar quantities of the test amino acid to that supplied in the standard diets.

The additional amino acids supplied by the test protein alter the amino acid balance in the diets compared to that in the standard diets and this can influence the utilization of test amino acid. For example, Sato et al. (1987) reported that the estimate of tryptophan availability in soya-bean meal for young pigs was increased by 0.17 units of availability as a result of supplementing the standard diet with free amino acids to provide the pattern of excess amino acids contributed by the soyabean meal. Chick response may also be influenced by the contribution of amino acids contributed by the test protein (see Baker, 1978). However, when compensating for the extra amino acids contributed by the test protein a problem exists to avoid overcompensation as the availabilities of the amino acids in the test protein are unknown. One also has to ensure that high levels of supplements of free amino acids do not have a depressing effect on appetite.

(2) Selecting a suitable criterion of response. The retention of the test amino acid in the empty body of the experimental animal would seem to be the most appropriate criterion 


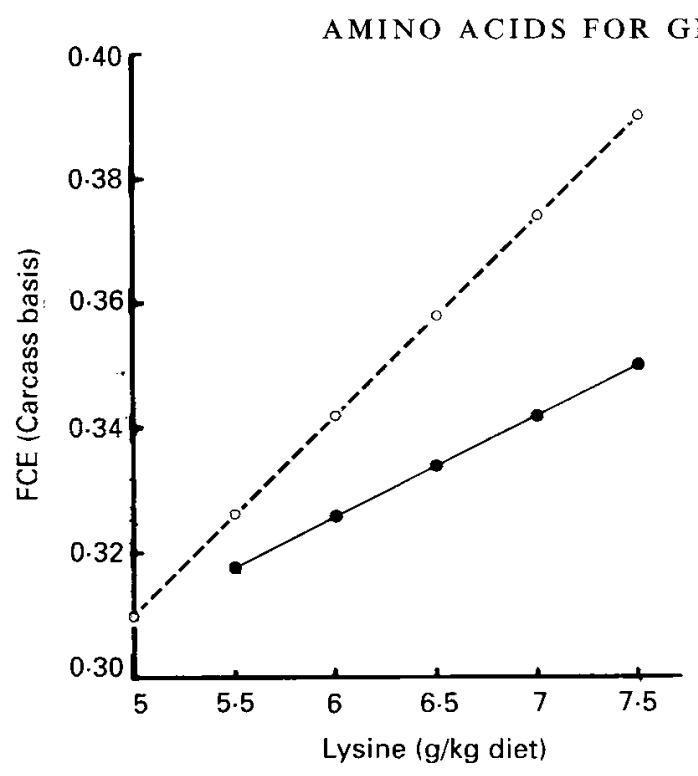

Fig. 1. Design of a slope-ratio assay for determining lysine availability. The response to increments of lysine in the test protein (-) is determined and expressed as a proportion of the response to standard free lysine $\left(\mathrm{O}_{--}-\mathrm{O}\right)$. FCE, feed conversion efficiency.

of response, but it is also the most expensive. In practice, with chicks, food conversion efficiency (FCE) has the advantage over growth response in that it takes into account differences in food intake that may develop (Carpenter \& Booth, 1973). For pigs, FCE on a carcass basis is preferable to using liveweight data as, with the latter, contributions of undigested material in the hind gut of the pigs given the test diets can result in overestimation by as much as 0.42 units of availability in fibrous protein sources (Batterham et al. 1981).

(3) The nature of the statistical analysis. Procedures for slope-ratio analyses have been outlined by Finney (1964). The parameter of response is regressed against dose level. With this analysis there are statistical safeguards to attempt to ensure that the responses are to the standard and test amino acids only. These include (i) ensuring that the response to the standard amino acid passes through the basal diet (designated blanks), (ii) linearity of response, (iii) lack of curvature (which may develop if the inclusion of test protein causes either a depressing (anti-nutritional factor) or stimulatory (nutrient limiting in the basal diet) effect) and (iv) a test to ensure the slopes of the responses to the standard and test amino acid intersect at the basal response point (blanks) this should occur if both slopes of responses are responding to the test amino acid only.

In practice, however, with most assays conducted under ad lib. feeding conditions, differences in food intake occur and regressing response against dose level is not appropriate. Rather, response is regressed against amino acid intake. The problem, however, with this analysis is that dietary intake is a mixture of the test amino acid (say lysine) contributed by the test protein and by the components of the basal diet. When differences in food intake occur, the contribution of lysine from the components in the basal diets varies between treatments and this confounds the assessment of availability of lysine in the test source. There are, however, statistical methods for partitioning responses to the various sources of lysine which attempt to minimize this problem.

(4) The estimate of availability has a relatively high standard error. This occurs as the estimate is based on the slopes of two responses which are both affected by individual variation of the test animals. 
A second factor contributing to variation in estimates is the accuracy of the total amino acid analysis of the test protein. Total amino acid analyses can vary by as much as $10 \%$ between laboratories and this will affect availability estimates by a similar amount.

As a result of both of the above factors it is not possible to detect small differences in availability between meals using growth assays.

It is interesting to note that digestibility assays are less susceptible to the effects of variation in total amino acid analysis of the test protein than growth assays. This occurs with digestibility assays as the undigested amino acid portion is usually only small relative to the total portion; thus a variation of $10 \%$ in the total amino acid analysis normally only affects the final digestibility estimates by about $1 \%$. In contrast, a similar variation in growth assays would affect the estimates of availability by the full $10 \%$.

\section{LYSINE AVAILABILITY FOR GROWING PIGS}

A growth assay has been developed and used for assessing the availability of lysine in major protein concentrates for growing pigs (Batterham et al. 1979, 1984). The features of this assay are as follows.

(1) The basal diet is based on high-protein wheat, wheat gluten and wheat starch, and requires only small additions of free amino acids to ensure that lysine is limiting. Test proteins are incorporated into the basal diet at the expense of wheat starch. Diets are equalized where possible for factors that might affect lysine availability, such as variation in fibre content contributed by vegetable protein concentrates. In addition, attempts are made to ensure that other factors contributed by the test protein do not influence the response (e.g. gossypol content in cottonseed meal).

(2) The diets are offered on a controlled feeding scale based on live weight. This prevents differences in amino acid balance or palatability of ingredients affecting intake. This in turn minimizes the problem of assessing quantity rather than quality when assessing amino acid response. In addition, the results can be analysed by the slope-ratio analysis of Finney (1964) regressing response against dose level.

(3) The diets are offered at three-hourly intervals to ensure full utilization of the free amino acids (Batterham \& Murison, 1981). This is achieved by use of an automatic frequent feeder (Fig. 2).

(4) A multi assay is used, with up to five test proteins assessed per assay and four or five dose levels per test protein.

(5) Pig response is assessed using FCE on a carcass basis regressed against lysine dose level in the diets.

The main features of the assay are (a) the use of controlled feeding, which is thought to minimize the effects of amino acid imbalance on the utilization of lysine and allows responses to be regressed against dose level, and $(b)$ the assessment of results on a carcass or empty body weight basis, which avoids the effects of variation in gut contents on availability estimates.

The results of a series of assays examining the major protein concentrates indicated that lysine availability (proportion of total) varied from 0.27 in cottonseed meal to 1.13 for blood meal (Table 1). The overall SEM of the estimates was high (around $0 \cdot 10$ ). Despite this, it is interesting to note that cottonseed meals were uniformly low in availability (estimates of $0.27,0 \cdot 29,0 \cdot 30,0.39$ and 0.43$)$ whilst soyabean meals were uniformly high $(0 \cdot 80,0 \cdot 84$, $0.89,0.90$ and 0.98 ).

With this order of accuracy, it is possible to grade protein sources into high $(>0.75)$, medium $(0 \cdot 50-0 \cdot 74)$ and low $(<0.50)$ quality meals. For some, such as meat and bone meals, 


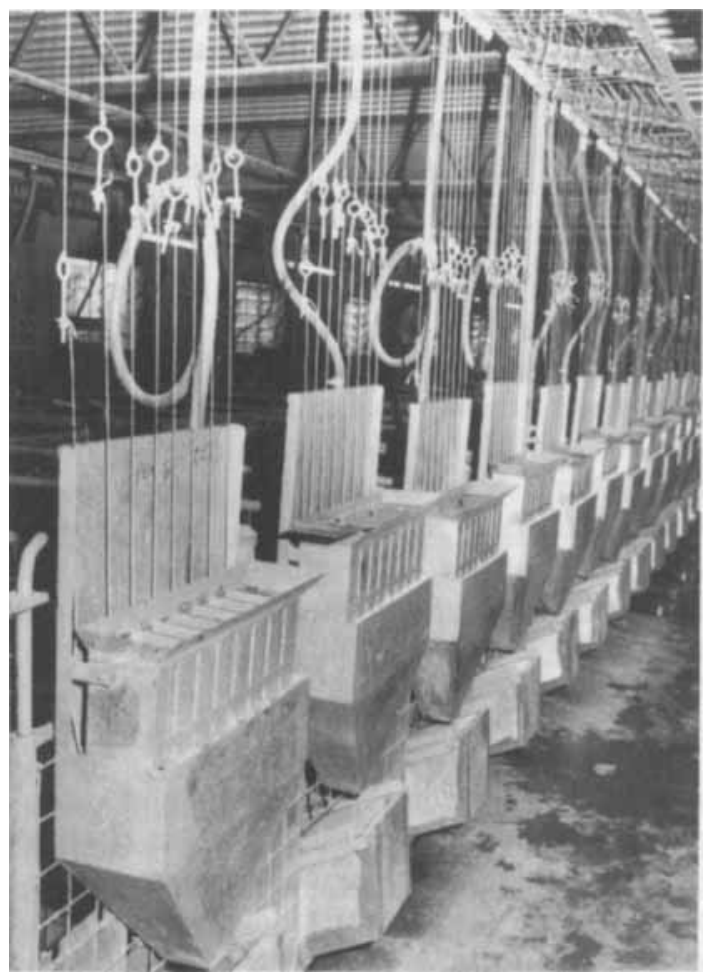

Fig. 2. An automatic frequent feeder for delivering feed at three-hourly intervals.

Table 1. Availability of lysine in protein concentrates for growing pigs

\begin{tabular}{lcc}
\hline \hline & \multicolumn{2}{c}{ Availability } \\
\cline { 2 - 3 } & Mean & Range \\
\hline Plood meal (ring-dried) & 1.08 & $1.03-1 \cdot 13$ \\
Cottonseed meal & 0.34 & $0.27-0.43$ \\
Field peas & 0.93 & - \\
Lupin-seed meal & 0.55 & $0.37-0.74$ \\
Meat meal and meat and bone meal & 0.68 & $0.42-0.97$ \\
Peanut meal & 0.57 & - \\
Rapeseed meal & 0.87 & $0.77-0.97$ \\
Skim milk powder & 0.85 & - \\
Soyabean meal & 0.88 & $0.80-0.98$ \\
Sunflower meal & 0.60 & 0.540 .66 \\
\hline
\end{tabular}

From Batterham et al. (1979, 1981, 1984, 1986a-c, 1990b).

lysine availability varied from low to high quality, which appeared to reflect differences in processing conditions (Batterham et al. 1986c).

The assay has also been applied to determining the effects of processing on meat and bone meal quality, where processing conditions were shown to alter the availability of lysine from 0.38 to 0.97 (Batterham et al. 1986b). 
Table 2. Growth responses and lysine retentions of pigs fed diets formulated to equal available lysine contents

\begin{tabular}{|c|c|c|c|c|c|}
\hline Diet No.... & $\begin{array}{c}1 \\
\operatorname{Cot}\end{array}$ & $\begin{array}{c}2 \\
\operatorname{Cot}+\text { Lys }\end{array}$ & $\begin{array}{c}3 \\
\text { Cot + Lys } \\
+ \text { AA }\end{array}$ & $\begin{array}{c}4 \\
\text { Soya }\end{array}$ & $\begin{array}{c}\text { LSD } \\
P=0.05\end{array}$ \\
\hline $\begin{array}{l}\text { Lysine }(\mathrm{g} / \mathrm{kg}) \\
\text { Total } \\
\text { Available }\end{array}$ & $\begin{array}{l}8 \\
4 \cdot 9\end{array}$ & $\begin{array}{c}10 \cdot 1 \\
7\end{array}$ & $\begin{array}{c}10 \cdot 1 \\
7\end{array}$ & $\begin{array}{l}8 \\
7\end{array}$ & \\
\hline $\begin{array}{l}\text { Gain }(\mathrm{g} / \mathrm{d}) \\
\text { FCE } \\
\text { Protein deposited }(\mathrm{g} / \mathrm{d}) \\
\text { Lysine retained: available } \\
\text { lysine intake }\end{array}$ & $\begin{array}{c}541 \\
0 \cdot 424 \\
74\end{array}$ & $\begin{array}{l}607 \\
0.470 \\
90\end{array}$ & $\begin{array}{l}610 \\
0.479 \\
94\end{array}$ & $\begin{array}{l}631 \\
0 \cdot 492 \\
99\end{array}$ & $\begin{array}{l}22 \\
0 \cdot 017 \\
5 \cdot 3\end{array}$ \\
\hline
\end{tabular}

From Batterham et al. $(1990 \mathrm{~b})$.

AA, amino acids; Cot, cottonseed meal; FCE, feed conversion efficiency; LSD, least significant difference; lys, lysine.

\section{VALIDITY OF ASSAY RESULTS}

The values for lysine availability from a cottonseed $(0 \cdot 30)$ and a soya-bean $(0 \cdot 90)$ meal were used to formulate diets of equal available lysine content (Batterham et al. 1990 b). In addition, the values for lysine availability were used to correct the estimated availability of other essential amino acids. The results (Table 2) indicated that diets formulated on a total lysine basis resulted in differences in growth response whereas, when the diets were formulated on an available lysine basis, similar growth, FCE, protein deposition and lysine retention, as a proportion of available lysine intake, occurred. These results confirmed that the availability values were more appropriate than total values in dietary formulations.

Overall, determining availability with growth assays is time-consuming, expensive, and limited in that only one amino acid can be assessed at a time. They also have relatively high SEM. They are therefore only useful in developing reference tables of availability of amino acids in major protein sources, for investigating processing conditions, and as reference values in the development of new techniques for estimating availability. There is a need for the development of more rapid techniques for predicting amino acid availability.

\section{ILEAL DIGESTIBILITY OF AMINO ACIDS}

The ileal digestibility assay has been used to estimate the availability of amino acids. With this assay, the digestibility of nutrients is determined with a sample of digesta containing an indigestible marker, which is collected from the terminal ileum. Amino acids progressing beyond the terminal ileum into the colon are assumed to be utilized by colonic microflora with only the nitrogen available to the host organism after absorption as ammonia. The assay has the advantage over faecal digestibility since interference from microbial utilization of amino acids in the hind gut is minimized, though not totally avoided. It also has the advantages that all essential amino acids can be determined at the one time, it is relatively inexpensive to conduct, the values have relatively low SEM, and the assay is robust. Techniques for and results of ileal digestibility assays for amino acids have been comprehensively reviewed by Sauer \& Ozimek (1986) and Low (1990).

The basis of the application of the ileal digestibility assay for estimating availability is the assumption that if an amino acid is digested and absorbed in the small intestine then it is 
in a form suitable for protein synthesis. As discussed earlier, this is a contentious point with nutritionists. In fact, at a symposium on nutrient availability at the XIIIth International Congress of Nutrition at Brighton in 1985 the audience was evenly divided on the topic and the Chairman suggested a moratorium on the use of the term 'availability' until a clear definition of its meaning was established. Interestingly, although most nutritionists held strong views on the subject, there appeared to be little or no comparative data on both techniques (growth and ileal digestibility assays).

There have been a number of studies that have shown that the use of ileal digestibility has an advantage over total or faecal digestibility values. For example, Tanksley \& Knabe (1984) determined the ileal digesitibilities of amino acids in a range of protein concentrates and cereals. Ileal digestibilities of amino acids in cottonseed meals and meat and bone meals were lower than in soyabean meals. In a subsequent evaluation of the results, pigs given diets formulated on a total amino acid basis from a mixture of soyabean and cottonseed or meat and bone meals grew slower than those given all soyabean meal. When the diets were formulated on an ileal digestible amino acid basis, similar pig responses resulted. These results indicated that ileal values were preferable to total values and were applicable for formulating diets. As a result of these and other experiments (see review by Low, 1990) ileal digestibility assay values are being used routinely by many feed formulators.

However, a number of recent studies have questioned the applicability of ileal digestibility values in diet formulations. Bellaver \& Easter (1989) reported that formulation of diets containing alternative proteins to soyabean meal did not support similar pig responses even though the diets were formulated on a true ileal digestibility basis; Wiseman et al. (1991) concluded that ileal apparent digestible amino acids from heat treated fish meal were not completely available to the pig; and Moughan et al. (1991) reported that estimates of the apparent ileal lysine digestibility in a well-balanced barley-meat and bone meal-fish meal-pollard diet overestimated the degree of lysine availability. These reports emphasize the need for further research to determine the relationship between ileal digestibility and availability.

\section{RELATIONSHIP BETWEEN ILEAL DIGESTIBILITY AND AVAILABILITY}

It is surprising that with the substantial amount of research that has been undertaken to develop and apply the ileal digestibility assay for determining amino acid digestibility, so little comparative research has been undertaken to verify the relationship between ileal digestibility and availability. This is particularly so in the light of earlier laboratory studies which indicated that derivatives of lysine, formed by the application of heat to protein concentrates, could be absorbed but inefficiently utilized (Hurrell et al. 1976). These effects, however, were difficult to quantify and it is not known to what extent, if any, they are important in commercial protein concentrates.

Leibholz (1985a) reported close agreement between the apparent ileal digestibility of lysine and calculated lysine retention in weaner pigs given five diets containing different protein concentrates. Similarly, Leibholz $(1985 \mathrm{~b})$ reported that the calculated retention of ileal digestible methionine ranged from 0.97 to 1.07 in weaner pigs given diets containing different protein concentrates. From these results, Leibholz $(1985 a, b)$ suggested that the ileal digestibility assay could be used to predict the availability of these amino acids.

Leibholz (1986) also reported that the availabilities of lysine in a number of protein concentrates for weaner pigs were higher than ileal digestibilities reported for similar proteins (Leibholz, 1985a) and were also higher than availability estimates of Batterham 
Table 3. Comparison of ileal digestibility and availability (proportion of total) of lysine in cottonseed and soyabean meals

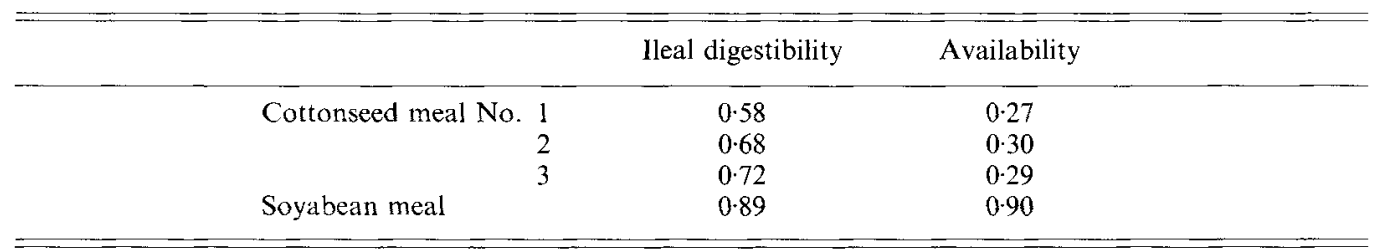

From Batterham et al. (1990b).

et al. (1979) for growing pigs. However, in the slope-ratio assays of Leibholz (1986) the responses were analysed by linear regression even though, in general, intersection was significant (the slopes of the lines of response of the test and standard lysine didn't pass through a common intersect). This statistical requirement is a safeguard to try to ensure that the responses are to the lysine in the test proteins and are not influenced by other dietary factors. As intersection was significant, it is highly likely that the availability estimates were influenced by other factors. In addition, the availability estimates were based on liveweight gain. As outlined earlier (pages 2 and 3), with growing pigs, availability estimates based on liveweight gain overestimate availability. Thus it is probable that the higher availability estimates reported by Leibholz (1986) were due to problems in methodology and the use of inappropriate criteria of response.

Green \& Kiener (1989) reported similar values for true digestibilities and availabilities of lysine in soya-bean $(0.84,0.82)$ and sunflower $(0.84,0.82)$ meals but concluded that as a result of the large standard errors associated with the availability estimates $(0 \cdot 12$ and $0 \cdot 18$ for soyabean and sunflower meals respectively) no meaningful comparisons could be made.

In a comparative study of ileal digestibility and availability of lysine, Batterham et al. $(1990 \mathrm{~b})$ reported that the values were similar for soyabean meal, but for three cottonseed meals ileal digestibility values were considerably higher than availabilities (Table 3). Subsequent testing of the values for lysine availability confirmed their applicability in dietary formulations (see Table 2). The authors concluded that for meals of high availability, there was close agreement between ileal digestibility and availability. However, in meals of low availability, ileal digestibility appeared to overestimate availability.

The above contrasting results indicate the need to establish more clearly the nature of the relationship between the ileal digestibility of amino acids and amino acid availability.

\section{UTILIZATION OF ILEAL DIGESTIBLE AMINO ACIDS}

The relationship between the ileal digestibility of amino acids and availability is currently being examined at Wollongbar. In essence, the project aims to determine whether ileal digestibility can be used to estimate amino acid availability, or if separate tests for measuring availability need to be developed for each essential amino acid.

Rather than develop individual availability assays for each of the essential amino acids and compare the results with ileal digestibility values, an alternative approach was adopted. Diets were formulated from different protein concentrates to an equal apparent ileal digestible amino acid content (say lysine) and the utilization of the ileal digestible lysine determined. If all the ileal digestible lysine was in a form suitable for protein synthesis then similar growth responses and retention of ileal digestible lysine should result. This procedure can be applied to all the essential amino acids by simply reformulating the diets 
to similar ileal digestible levels of say threonine and assessing threonine utilization. This is much simpler than developing separate slope-ratio assays for each of the essential amino acids for comparative studies.

Semisynthetic diets were used, with the test protein as the only protein source in sugarbased diets. This approach avoids any interference of nutrients contributed by the conventional cereal base and allows a direct determination of the utilization of the test amino acid from a protein concentrate. The diets were supplemented with free amino acids to an approximate 0.30 surplus, to ensure that the test amino acid was limiting. An additional three diets were also supplemented with the test amino acid to verify that it was in fact limiting. The diets were given to growing pigs at a feeding scale of three times maintenance over the $20-45 \mathrm{~kg}$ growth phase. At the completion of the experiment, the protein and amino acid compositions of the empty bodies of the pigs were determined.

Three protein concentrates were used in the studies-soyabean meal (representing a high-quality protein), meat and bone meal (medium-quality protein) and cottonseed meal (low-quality protein). These three meals covered the approximate range in lysine availabilities (estimated as 0.90 to 0.30 ). The apparent ileal digestibility of amino acids in the three proteins was initially determined and the values used in the subsequent experiments.

\section{LYSINE}

For the lysine experiment, diets were formulated with the cottonseed, meat and bone, and soya-bean meals as the only source of ileal digestible lysine $(0.36 \mathrm{~g} / \mathrm{MJ}$ digestible energy (DE)) in sugar-based diets.

The results (Table 4) for lysine indicated that growth performance of the pigs was markedly inferior when given ileal digestible lysine from cottonseed meal relative to soyabean meal. Furthermore, the retention of ileal digestible lysine from cottonseed meal was only 0.36 compared to 0.75 for pigs given soyabean meal. These results show that a considerable proportion of the ileal digestible lysine from cottonseed meal and meat and bone meal was apparently absorbed in a form(s) that was inefficiently utilized by the pig. As such, the ileal digestibility assay overestimated availability in heat-damaged proteins. This finding supported earlier work of Batterham et al. (1990 b).

\section{THREONINE}

Diets were reformulated with the protein sources as the only source of ileal digestible threonine $(0.22 \mathrm{~g} / \mathrm{MJ} \mathrm{DE})$.

Similar results to lysine were recorded for threonine (Table 4). Growth performance and the retention of ileal digestible threonine was lower for the pigs given cottonseed meal compared to soyabean meal. The proportion of ileal digestible threonine retained by the pigs was only 0.44 for pigs given cottonseed meal compared to 0.64 for pigs given soyabean meal.

These results indicate that, as for lysine, a considerable proportion of ileal digestible threonine was apparently absorbed in a form(s) that was inefficiently utilized. This indicated that ileal digestible values overestimated threonine availability in heat-damaged meals.

\section{METHIONINE}

A level of $0.09 \mathrm{~g}$ ileal digestible methionine/MJ DE was used in the methionine experiment. Growth performance and protein deposition was again lower for the pigs given cottonseed meal compared to soyabean meal (Table 4). However, there was little difference in the 
Table 4. Growth responses and retention of ileal digestible amino acids by growing pigs given diets formulated to equal ileal digestible amino acid contents

\begin{tabular}{|c|c|c|c|c|}
\hline \multirow[b]{2}{*}{ Response } & \multicolumn{3}{|c|}{ Diets } & \multirow[b]{2}{*}{ SEM } \\
\hline & $\begin{array}{c}1 \\
\operatorname{Cot}\end{array}$ & $\stackrel{2}{2}$ & $\begin{array}{c}3 \\
\text { Soya }\end{array}$ & \\
\hline \multicolumn{5}{|l|}{ Expt 1. Lysine } \\
\hline Gain $(g / d)$ & 377 & 492 & 541 & $11 \cdot 5$ \\
\hline Food conversion ratio & $3 \cdot 5$ & $2 \cdot 6$ & $2 \cdot 3$ & 0.07 \\
\hline Protein deposited $(\mathrm{g} / \mathrm{d})$ & 38 & 66 & 77 & 1.6 \\
\hline $\begin{array}{l}\text { Lysine retained: ileal } \\
\text { digestible lysine intake }\end{array}$ & 0.36 & 0.60 & 0.75 & 0.012 \\
\hline \multicolumn{5}{|l|}{ Expt 2. Threonine } \\
\hline Gain $(\mathrm{g} / \mathrm{d})$ & 417 & 452 & 524 & $9 \cdot 6$ \\
\hline Food conversion ratio & $3 \cdot 2$ & $2 \cdot 8$ & $2 \cdot 4$ & 0.04 \\
\hline Protein deposited $(\mathrm{g} / \mathrm{d})$ & 47 & 62 & 75 & $2 \cdot 3$ \\
\hline $\begin{array}{l}\text { Threonine retained: ileal } \\
\text { digestible threonine intake }\end{array}$ & $0 \cdot 44$ & 0.59 & 0.64 & 0.017 \\
\hline \multicolumn{5}{|l|}{ Expt 3. Methionine } \\
\hline Gain $(g / d)$ & 411 & 441 & 496 & 17.4 \\
\hline Food conversion ratio & $3 \cdot 1$ & $2 \cdot 7$ & $2 \cdot 5$ & $0 \cdot 07$ \\
\hline Protein deposited $(\mathrm{g} / \mathrm{d})$ & 47 & 57 & 61 & $2 \cdot 3$ \\
\hline $\begin{array}{l}\text { Methionine retained: ileal } \\
\text { digestible methionine intake }\end{array}$ & 0.38 & 0.45 & $0 \cdot 45$ & 0.013 \\
\hline \multicolumn{5}{|l|}{ Expt 4. Tryptophan } \\
\hline Gain $(g / d)$ & 393 & 531 & 437 & $27 \cdot 7$ \\
\hline Food conversion ratio & $2 \cdot 9$ & $2 \cdot 4$ & $2 \cdot 4$ & 0.07 \\
\hline Protein deposited $(\mathrm{g} / \mathrm{d})$ & 54 & 75 & 63 & 3.5 \\
\hline $\begin{array}{l}\text { Tryptophan retained: ileal } \\
\text { digestible tryptophan intake }\end{array}$ & 0.46 & 0.45 & 0.38 & 0.010 \\
\hline
\end{tabular}

Diets were formulated to $0.36 \mathrm{~g}$ ileal digestible lysine/MJ DE (Expt 1), $0.22 \mathrm{~g}$ ileal digestible threonine/MJ DE (Expt 2), $0.09 \mathrm{~g}$ ileal digestible methionine/MJ DE (Expt 3) and $0.065 \mathrm{~g}$ ileal digestible tryptophan/MJ DE (Expt 4).

From Batterham et al. (1990a) (Expt 1), Beech et al. (1991) (Expt 2) and Batterham, E. S., unpublished data. Cot, cottonseed meal; DE, digestible energy; meat, meat and bone meal; soya, soyabean meal.

retention of ileal digestible methionine in pigs given the three protein sources, although overall retentions were low relative to those recorded with lysine and threonine.

Overall the results indicated that ileal digestible values overestimated methionine availability in heat-damaged meals.

\section{TR Y PTOPHAN}

Diets were formulated to $0.065 \mathrm{~g}$ ileal digestible tryptophan/MJ DE. With this experiment, it was not possible to supply the tryptophan from meat and bone meal only, as this would have resulted in excessive calcium levels in the diet. Accordingly, with this diet, approximately half the tryptophan was supplied as a supplement of free tryptophan. There was considerable variation in pig response, with those pigs given the combination of meat and bone meal plus free tryptophan growing faster than those given cottonseed or soyabean meals (Table 4). The retention of ileal digestible tryptophan was similar for pigs given cottonseed or meat and bone meals, and slightly higher than for those given soyabean meal. 
These results are surprising and tend to indicate that the free tryptophan supplement had greater growth promoting ability than the ileal digestible tryptophan in the diets. Also interesting were very low retentions of tryptophan by the pigs, which were similar to those recorded for methionine.

These results are difficult to interpret but again indicate that the ileal digestible values for tryptophan did not appear to reflect availability.

\section{ISOLEUCINE, LEUCINE AND VALINE}

For the determination of the utilization of ileal digestible isoleucine, leucine and valine, cottonseed meal, lupin-seed meal and soyabean meal were used as protein sources. The same experimental procedure was used as before, with the diets formulated to similar quantities of either ileal digestible isoleucine, leucine or valine from the three protein sources.

The results for these three amino acids were contrary to the previous four amino acids, as there were no differences in growth performances or estimated retentions in pigs fed the three diets. The results for isoleucine are given in Table 5 and similar results were recorded for leucine and valine.

Table 5. Growth responses and retention of ileal digestible isoleucine by growing pigs fed diets formulated to $0.23 \mathrm{~g}$ ileal digestible isoleucine/MJ digestible energy

\begin{tabular}{|c|c|c|c|c|}
\hline \multirow[b]{2}{*}{ Response } & \multicolumn{3}{|c|}{ Diets } & \multirow[b]{2}{*}{ SEM } \\
\hline & $\stackrel{1}{\mathrm{Cot}}$ & $\begin{array}{c}2 \\
\text { Lupin }\end{array}$ & $\begin{array}{c}3 \\
\text { Soya }\end{array}$ & \\
\hline Gain $(g / d)$ & 590 & 613 & 594 & $13 \cdot 0$ \\
\hline Protein deposited $(\mathrm{g} / \mathrm{d})$ & 84 & 87 & 91 & $2 \cdot 3$ \\
\hline $\begin{array}{l}\text { Estimated isoleucine } \\
\text { retention: ileal digestible } \\
\text { isoleucine intake }\end{array}$ & 0.63 & 0.63 & 0.67 & 0.014 \\
\hline
\end{tabular}

From Batterham, E. S., unpublished data.

Cot, cottonseed meal; lupin, lupin-seed meal; soya, soyabean meal.

These results indicate that the branched chain amino acids, isoleucine, leucine and valine, appear less sensitive to heat damage and the ileal digestibility of these amino acids reflects availability. These amino acids differ from the other amino acids in that they are metabolized mainly in muscle tissue. It is possible that these amino acids are less susceptible to the effects of heat during processing or that any changes induced have little or no effect on subsequent protein synthesis in the muscle tissue.

\section{SUMMARY}

The results of the utilization studies indicate that amino acids vary in their sensitivity to processing conditions. Lysine, threonine, methionine and tryptophan seem sensitive, and changes in their amino acid profiles appear to occur which do not necessarily affect digestibility, but render the amino acid unavailable for protein synthesis. As a consequence, ileal digestibility overestimates availability of these amino acids in heat-damaged meals.

It was also interesting to note that there were differences in the apparent sensitivity of 


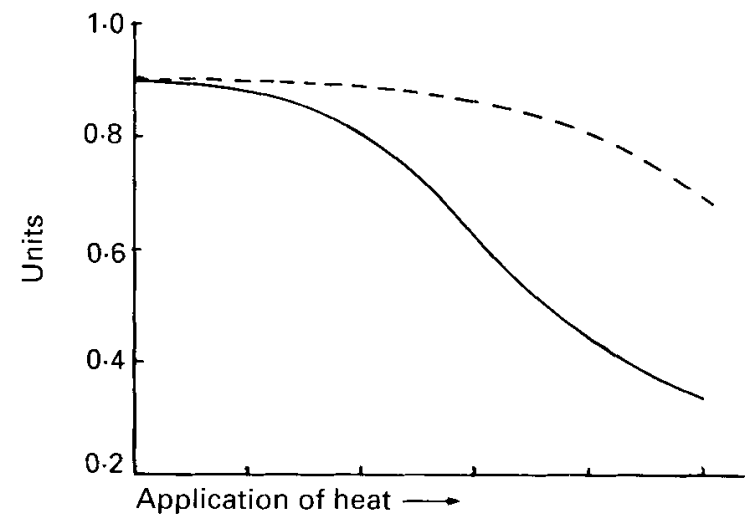

Fig. 3. Hypothetical effect of heat on the ileal digestibility (_-_) and availability (___--) of lysine in a protein concentrate.

Table 6. Growth responses and estimated lysine retention of growing pigs fed diets containing heat-treated field peas and formulated to $0 \cdot 36 \mathrm{~g}$ ileal digestible lysine $/ M J$ digestible energy

\begin{tabular}{|c|c|c|c|c|c|c|}
\hline \multirow[b]{2}{*}{ Response } & \multicolumn{6}{|c|}{ Treatment } \\
\hline & Raw & $110^{\circ}$ & $135^{\circ}$ & $150^{\circ}$ & $165^{\circ}$ & SEM \\
\hline Gain $(g / d)$ & 498 & 482 & 477 & 450 & 314 & $12 \cdot 9$ \\
\hline Feed conversion ratio & $2 \cdot 6$ & $2 \cdot 7$ & $2 \cdot 8$ & $2 \cdot 9$ & 4.5 & $0 \cdot 12$ \\
\hline $\begin{array}{l}\text { Estimated lysine retained: } \\
\text { ileal digestible lysine intake }\end{array}$ & $0 \cdot 72$ & 0.65 & 0.64 & $0 \cdot 58$ & 0.42 & 0.021 \\
\hline
\end{tabular}

From Van Barneveld et al. (1991 b).

lysine, threonine, methionine and tryptophan to heat damage. Thus, for these four amino acids, separate techniques for measuring availability appear warranted.

In contrast, the branched chain amino acids, isoleucine, leucine and valine, appeared less sensitive to processing damage and the ileal digestibility assay appears suitable for estimating availability.

There were also large differences in the retention of individual amino acids. For pigs given soyabean meal, retentions varied from 0.75 for lysine to 0.38 for tryptophan.

\section{EFFECT OF HEAT ON LYSINE AVAILABILITY}

The above comparisons of ileal digestibility and availability of lysine in soyabean and cottonseed meals indicate that $(a)$ with high-quality meals, ileal digestibility and availability were similar, indicating that loss of ileal digestibility was the major reason for loss of availability and $(b)$ with heat-damaged meals, changes occur to the lysine molecule which apparently have little effect on digestibility but a more marked effect on availability. Thus, availability falls to a greater extent than ileal digestibility. This hypothesis is illustrated in Fig. 3.

The hypothesis is supported by earlier work in the literature which indicates that when heat is applied to a protein the fall in biological value is greater than the fall in digestibility (Hurrell et al. 1976). 
In order to validate this hypothesis, experiments are currently under way at Wollongbar examining the effect of heat on total amino acid content, faecal and ileal digestibility of amino acids, retention of ileal digestible lysine and the availability of lysine.

Preliminary results from these studies support the hypothesis and confirm that heat is the causal agent depressing lysine utilization. The application of heat to field peas significantly depressed the total lysine concentration, whereas the concentrations of the branched chain amino acids, isoleucine, leucine and valine, were slightly increased (Van Barneveld $e t$ al. $1991 a$ ). This is in agreement with the results of the retention studies which indicate that the branched chain amino acids are less sensitive to heat damage than the other amino acids. Lysine retention studies with the heated field peas have indicated that, as heat was applied, an increasing proportion of ileal digestible lysine was apparently absorbed in a form that was inefficiently utilized (Table 6).

\section{NON-UTILIZED FORMS OF LYSINE}

Lysine has been considered more susceptible to reactions with other compounds as it is a dibasic amino acid and has a free $\epsilon$-amino group when bound in a peptide linkage. When heat is applied to a protein in the presence of reducing sugars, this amino group forms complex Maillard-type reactions (Carpenter \& Booth, 1973). In the initial stages, lysinesugar complexes such as fructoselysine and lactuloselysine are formed (Erbersdobler, 1977). These compounds are digestible but are unlikely to be utilized unless the kidneys have the necessary enzymes to release the lysine, so they are excreted in the urine. Early Maillard damage occurs especially in the application of mild heat to milk products. Late Maillard damage is more likely to occur with the application of heat during the processing of industry byproducts, such as meat and bone meals and cottonseed meals, and results in the formation of compounds that are considered largely indigestible. Advanced Maillard reactions not only reduce digestibility, but can also destroy lysine and other amino acids (Hurrell \& Carpenter, 1977).

In the absence of reducing sugars, the free $\epsilon$-amino group of lysine can also react with other amino acid side chains or disrupted bonds to form isopeptides such as aspartyl-lysine, glutamyl-lysine or lysinoalanine (Hurrell \& Carpenter, 1977). Again these compounds can be absorbed but their nutritional value is more difficult to assess (Hurrell \& Carpenter, 1977). Lysinoalanine has also been shown to have toxic properties (Pfaender, 1983).

A more detailed account of the effects of heat on the utilization of lysine is given in the reviews of Carpenter \& Booth (1973), Erbersdobler (1977) and Hurrell \& Carpenter (1977).

Whilst a number of studies have shown that heat damage results in the formation of small peptides, it is analytically difficult to identify these compounds, trace their metabolism and quantify their effects (Ford \& Shorrock, 1971; Hurrell et al. 1976). For these reasons it is not known how important these compounds are in commercial protein concentrates. The ileal amino acid utilization studies indicate that they may account for up to half the absorbed lysine in heated meals. It is also evident from the above studies that similar reactions most probably occur with threonine, methionine and tryptophan.

There is a need to identify these compounds fully if the mechanisms of heat damage are to be understood and techniques developed to predict the availability of amino acids in heat damaged proteins.

\section{SPECIES DIFFERENCES IN ABILITY TO UTILIZE LYSINE}

There has always been an interest in using the results from one species to predict availability in other species. This applies particularly to the use of short term rat or chick assays for 
Table 7. Comparison of the availabilities of lysine (proportion of total) in protein concentrates for pigs, rats and chicks

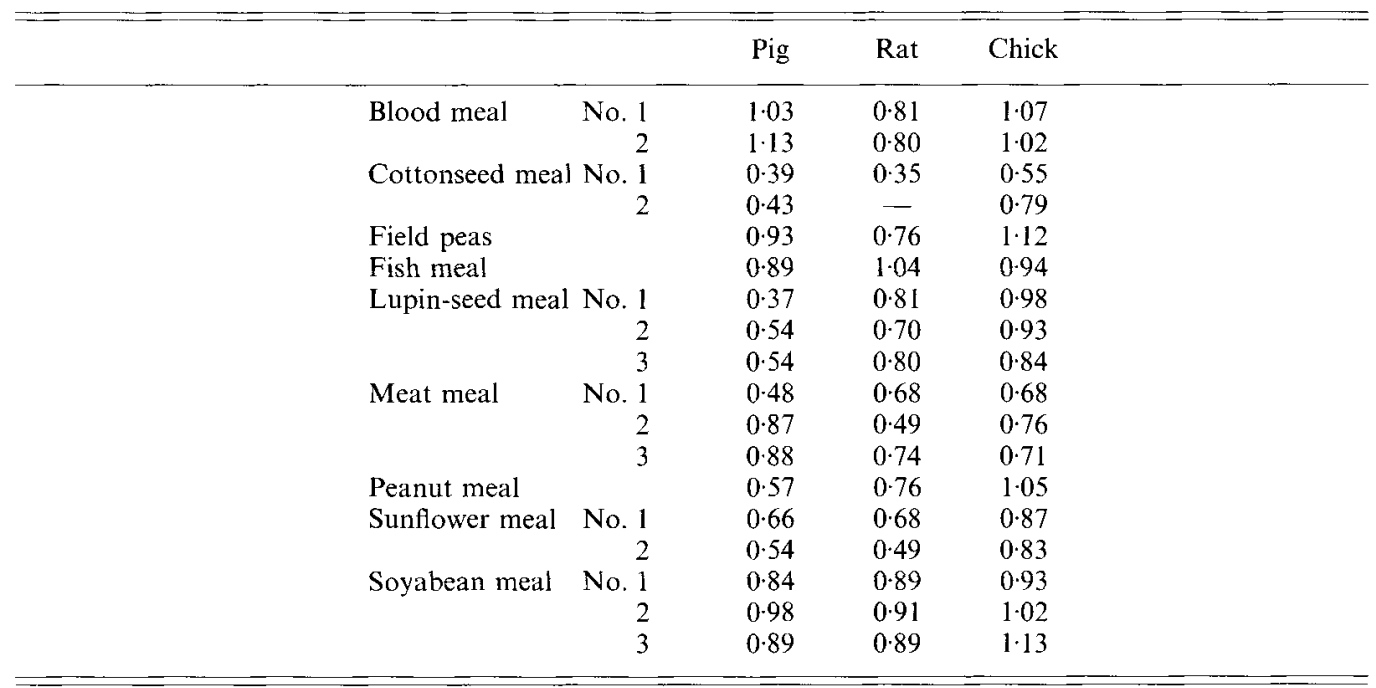

From Batterham et al. (1979, 1981, 1984, 1986c), Major \& Batterham (1981) and Major, E J. and Batterham, E. S., unpublished data.

predicting pig response. However, in comparative availability studies with growth assays, there was little relationship in the availabilities of lysine for these three species (Table 7).

Part of these differences may reflect differences in methods. Difficulties were experienced with the growth assay for chicks, where values greater than 1.0 for availability were often encountered. The reason for this was not established but may reflect the difficulty of developing suitable availability assays for chicks and the problem of minimizing the effects of amino acid patterns contributed by the test proteins under ad lib. feeding conditions (Baker, 1978).

In contrast to the chick results, values over 1.0 were seldom encountered with the rat assay, which was also conducted under ad lib. feeding, or with the pig assay, which was conducted using controlled feeding. The latter is thought to minimize the effect of the pattern of amino acids contributed by the test protein on the utilization of the test amino acid.

Nevertheless, the results of the comparative study suggest that species differences in ability to utilize lysine occur. This is possible, as there are species differences in the ability to utilize different forms of lysine. For example, $\epsilon-N$-propionyl-L-lysine (a synthetic model used to study lysine availability) has no value for rats (Bjarnason \& Carpenter, 1969) but has a potency of 0.72 for chicks (Varnish \& Carpenter, 1975) apparently due to differences in substrate specificity of $\epsilon-N$-lysine acylase in the two species. Green \& Kiener (1989) also reported that there were differences in the digestibilities of amino acids in protein concentrates for pigs and chicks.

Overall, these results indicate that species differences exist in ability to utilize amino acids from different proteins, and therefore availability studies should be conducted on the target species. 


\section{NEW TECHNIQUES FOR DETERMINING AVAILABILITY}

It is evident from the ileal digestibility utilization studies that there is a need for new techniques for assessing the availability of lysine, threonine, methionine and tryptophan for growing pigs. Growth assays are suitable only as a research technique and are unsuitable for use on a routine basis. Furthermore, developing suitable basal diets for threonine, methionine and tryptophan would be more difficult and expensive than for lysine, which is normally the major limiting amino acid in cereal-based diets.

The requirement for an assay for assessing availability is that it should be based on a measurement of the utilization of the test amino acid when it is limiting in the diet.

An alternative assay proposed by Black \& Batterham (1987) involved the use of $\left[{ }^{14} \mathrm{C}\right]$ lysine to monitor lysine oxidation, which can be assessed by measuring the quantity of ${ }^{14} \mathrm{CO}_{2}$ exhaled by the pig. This technique would be insensitive for measuring lysine availability using lysine-deficient diets, as the majority of the $\left[{ }^{14} \mathrm{C}\right]$ lysine would be incorporated into body protein. However, they proposed to measure lysine oxidation from the incorporation of free lysine and test protein into a basal diet already containing a surplus of lysine. The increase in the amount of ${ }^{14} \mathrm{CO}_{2}$ respired from pigs given the diet containing the test protein, relative to that from free lysine, would be a measure of lysine availability in the test protein. By repeating the treatments on the same pigs in a latin square design, it would be possible to conduct an assay in approximately one week and minimize genotype and environmental effects on the availability values.

Unfortunately, preliminary determinations with the technique have indicated that the variation associated with the measurements is high. This aspect is currently being investigated.

For the branched chain amino acids, isoleucine, leucine and valine, the ileal digestibility assay would seem the most appropriate way to assess availability, as these amino acids appear less sensitive to heat damage.

\section{TECHNIQUES FOR PREDICTING AVAILABILITY}

The majority of chemical tests for predicting lysine availability were based on a measurement of the free $\epsilon$-amino group of lysine in proteins. The techniques were based on the assumption that if the $\epsilon$-amino group of lysine was free, then that lysine molecule was nutritionally available. It was assumed that the $\epsilon$-amino group of lysine reacted with other compounds, principally carbonyl groups of reducing sugars, especially when heat was applied during processing, to form indigestible Maillard compounds. A number of chemical dyes were used, the principal one being 1-fluoro-2,4-dinitrobenzene (FDNB). It was also assumed that lysine, bsing dibasic, was more susceptible to reactions with other compounds than other amino acids.

However, there was little agreement between assay values from these techniques (or other similar techniques) and lysine availability for pigs (Table 8). Whilst there was often good agreement between assay values and lysine availability for meals of high availability, the chemical techniques tended to overestimate availability in meals of low availability.

The current utilization studies indicate that other amino acids in cottonseed meal are also susceptible to the effects of heat processing, particularly threonine, methionine and tryptophan. It is possible that all of these amino acids undergo reactions with other amino acids within the protein molecule and that this contributes to the reduced availability. This would also account for the chemical techniques which estimated only the free $\epsilon$-amino group of lysine overestimating availability. Once the mechanisms of heat damage have been elucidated, it may be possible to develop prediction techniques based on the presence of the various derivatives of these amino acids which are formed with the application of heat. 
Table 8. Availability of lysine (proportion of total) in protein concentrates for growing pigs and as estimated with chemical tests that were based on either direct or indirect reactions with fluorodinitrobenzene (FDNB)

\begin{tabular}{|c|c|c|c|}
\hline \multirow[b]{2}{*}{ Protein concentrate } & \multirow{2}{*}{$\begin{array}{c}\text { Lysine } \\
\text { availability } \\
\text { for pigs }\end{array}$} & \multicolumn{2}{|c|}{$\begin{array}{l}\text { Chemical estimates of } \\
\text { lysine availability }\end{array}$} \\
\hline & & $\begin{array}{c}\text { Direct } \\
\text { FDNB }\end{array}$ & $\begin{array}{l}\text { Indirect } \\
\text { FDNB }\end{array}$ \\
\hline Blood meal (ring dried) & 1.03 & 0.97 & $0 \cdot 91$ \\
\hline Cottonseed meal & 0.43 & 0.65 & 0.93 \\
\hline Field peas & $0-93$ & 0.83 & 0.98 \\
\hline Fish meal & 0.89 & 0.90 & 0.89 \\
\hline Lupin-seed meal & 0.54 & 0.76 & 0.97 \\
\hline Meat meal No. 1 & $0 \cdot 48$ & 0.80 & 0.79 \\
\hline 2 & 0.59 & 0.90 & 0.84 \\
\hline 3 & $0-88$ & 0.84 & 0.82 \\
\hline Peanut meal & 0.57 & 080 & 0.91 \\
\hline Skim-milk powder & 0.85 & 0.79 & 0.96 \\
\hline Sunflower meal & 0.59 & 0.46 & 0.92 \\
\hline Soyabean meal & $0 \cdot 84$ & 0.77 & 0.93 \\
\hline
\end{tabular}

From Batterham et al. $(1979,1981,1984,1986 c)$.

It is likely that in vitro techniques for predicting digestibility will only be useful in meals of high availability, where there is a good relationship between ileal digestibility and availability. They are less likely to be useful when availability is depressed by the application of heat, as the fall in digestibility only accounts for a small proportion of the loss in availability. It seems essential that any technique to predict availability be based on a measurement of a parameter or parameters which affect protein synthesis.

However, for the branched chain amino acids, in vitro techniques to predict digestibility should have application, as changes in ileal digestibility appear to account for the major changes in availability.

Of particular interest is the application of near infra-red (NIR) spectrophotometry (or similar technology) to predict amino acid availability. NIR analysis has the advantage that it is rapid and inexpensive to conduct. If the changes to the amino acid profile that are induced by heat affect the reflectance qualities of the protein, then it should be possible to detect these changes with NIR. However, the major limitation to developing NIR analyses is the need for suitable standards for calibrating the equipment. It would seem necessary to develop separate calibration curves for individual protein concentrates for the four major amino acids and this would be a substantial undertaking.

\section{CONCLUSIONS}

Amino acids vary in their susceptibility to processing conditions. For lysine, threonine, methionine and tryptophan, heat induces changes which depress ileal digestibility slightly but result in a substantial proportion of these amino acids apparently being absorbed in an inefficiently utilized form(s). Thus, the ileal digestibility assay is unsuitable for assessing availability in heat-damaged meals. Separate techniques for assessing amino acid availability are needed for these amino acids.

In contrast, the branched chain amino acids, isoleucine, leucine and valine, appear less susceptible to the effects of heat. For these amino acids, reduced ileal digestibility appears 
to be the main cause of reduced availability. Thus, the ileal digestibility assay can be used to estimate amino acid availability.

Growth assays with pigs are expensive, time consuming techniques and are only suitable for determining relatively large differences in amino acid availability. More rapid and inexpensive techniques are needed for determining or predicting availability. Such techniques are unlikely to be developed until the biochemical mechanisms underlying the causes of reductions in amino acid availability are better understood.

An alternative for predicting amino acid availability is the use of technology such as NIR spectrophotometry. This should have application if the mechanisms of reduced availability affect the reflectance characteristics of proteins.

\section{REFERENCES}

Baker, D. H. (1978). Nutrient bioavailability in feedstuffs: methodology for determining amino acid and Bvitamin availability in cereal grains and soybean meal. Proceedings of the 1978 Georgia Nutrition Conference, Atlanta, pp. 1-12.

Batterham, E. S., Andersen, L. M., Baigent, D. R., Beech, S. A. \& Elliott, R. (1990a). Utilization of ileal digestible amino acids by pigs: lysine. British Journal of Nutrition 64, 679-690.

Batterham, E. S., Andersen, L. M., Baigent, D. R., Darnell, R. E. \& Taverner, M. R. (1990 b). A comparison of the availability and ileal digestibility of lysine in cottonseed and soyabean meals for grower/finisher pigs. British Journal of Nutrition 64, 663-677.

Batterham, E. S., Andersen, L. M., Lowe, R. F. \& Darnell, R. E. (1986a). Nutritional value of lupin (Lupinus albus)-seed meal for growing pigs: availability of lysine, effect of autoclaving and net energy content. British Journal of Nutrition 56, 645-659.

Batterham, E. S., Darnell, R. E., Herbert, L. S. \& Major, E. J. (1986 b). Effect of pressure and temperature on the availability of lysine in meat and bone meal as determined by slope-ratio assays with growing pigs, rats and chicks and by chemical techniques. British Journal of Nutrition 55, 441-453.

Batterham, E. S., Lowe, R. F., Darnell, R. E. \& Major, E. J. (1986c). Availability of lysine in meat meal, meat and bone meal and blood meal as determined by the slope-ratio assay with growing pigs, rats and chicks and by chemical techniques. British Journal of Nutrition 55, 427-440.

Batterham, E. S. \& Murison, R. D. (1981). Utilization of free lysine by growing pigs. British Journal of Nutrition 46, 87-92.

Batterham, E. S., Murison, R. D. \& Andersen, L. M. (1984). Availability of lysine in vegetable protein concentrates as determined by the slope-ratio assay with growing pigs and rats and by chemical techniques. British Journal of Nutrition 51, 85-99.

Batterham, E. S., Murison, R. D. \& Lewis, C. E. (1979). Availability of lysine in protein concentrates as determined by the slope-ratio assay with growing pigs and rats and by chemical techniques. British Journal of Nutrition 41, 383-391.

Batterham, E. S., Murison, R. D. \& Lowe, R. F. (1981). Availability of lysine in vegetable protein concentrates as determined by the slope-ratio assay with growing pigs and rats and by chemical techniques. British Journal of Nutrition 45, 401-410.

Beech, S. A., Batterham, E. S. \& Elliott, R. (1991). Utilization of ileal digestible amino acids by growing pigs: threonine. British Journal of Nutrition 65, 381-390.

Bellaver, C. \& Easter, R. A. (1989). Performance of pigs fed diets formulated on the basis of amino acid digestibility. Journal of Animal Science 67, Suppl., 241

Bjarnason, J. \& Carpenter, K. J. (1969). Mechanisms of heat damage in proteins. 1. Models with acylated lysine units. British Journal of Nutrition 23, 859-868.

Black, J. L. \& Batterham, E. S. (1987). A proposed method for determining amino acid availability in pig diets. In Manipulating Pig Production, p. 145. Werribee: Australasian Pig Science Association.

Carpenter, K. J.\& Booth, V. H. (1973). Damage to lysine in food processing: its measurement and its significance. Nutrition Abstracts and Reviews 43, 423-451.

Erbersdobler, H. F. (1977). The biological significance of carbohydrate-lysine crosslinking during heat-treatment of food proteins. In Protein Crosslinking: Nutritional and Medical Consequences (Advances in Experimental Medicine and Biology vol. 86B) pp. 367-378 [M. Friedman, editor]. New York: Plenum Press.

Finney, D. J. (1964). Statistical Method in Biological Assay, 2nd edn. London: Griffin.

Ford, J. E. \& Shorrock, C. (1971). Metabolism of heat-damaged proteins in the rat. Influence of heat damage on the excretion of amino acids and peptides in the urine. British Journal of Nutrition 26, 311-322.

Green, S. \& Kiener, T. (1989). Digestibilities of nitrogen and amino acids in soyabean, sunflower, meat and rapeseed meals measured with pigs and poultry. Animal Production 48, 157-179. 
Hurrell, R. F. \& Carpenter, K. J. (1977). Nutritional significance of crosslink formation during food processing. In Protein Crossitinking: Nutritional and Medical Consequences (Advances in Experimental Medicine and Biology vol. 86B), pp. 225-238 [M. Friedman, editor]. New York: Plenum Press.

Hurrell, R. F., Carpenter, K. J., Sinclair, W. J., Otterburn, M. S. \& Asquith, R. S. (1976). Mechanisms of heat damage in proteins. 7. The significance of lysine-containing isopeptides and of lanthionine in heated proteins. British Journal of Nutrition 35, 383-395.

Leibholz, J. (1985a). An evaluation of total and digestible lysine as a predictor of lysine availability in protein concentrates for young pigs. British Journal of Nutrition 53, 615-624.

Leibholz, J. (1985b). The digestion of protein in young pigs and the utilization of dietary methionine. British Journal of Nutrition 53, 137-147.

Leibholz, J. (1986). The utilization of lysine by young pigs from nine protein concentrates compared with free lysine in young pigs fed ad lib. British Journal of Nutrition 55, 179-186.

Low, A. G. (1990). Protein evaluation in pigs and poultry. In Feedstuff Evaluation, pp. 91-114 [J. Wiseman and D. J. A. Cole, editors]. London: Butterworths.

Major, E. J. \& Batterham, E. S. (1981). Availability of lysine in protein concentrates as determined by the sloperatio assay with chicks and comparisons with rat, pig and chemical assays. British Journal of Nutrition 46, 513-519.

Moughan, P. J., Smith, W. C., Pearson, G. \& James, K. A. C. (1991). Assessment of apparent ileal lysine digestibility for use in diet formulation for the growing pig. Animal Feed Science and Technology 34, 95-109.

Pfaender, P. (1983). Lysinoalanine-a toxic compound in processed proteinaceous foods. In Aspects of Human and National Nutrition (World Review of Nutrition and Dietetics vol. 41), pp. 97-109 [G. H. Boume, editor]. Basel: Karger.

Sato, H., Kobayashi, T., Jones, R. W. \& Easter, R. A. (1987). Tryptophan availability of some feedstuffs determined by pig growth assay. Journal of Animal Science 64, 191-200.

Sauer, W. C. \& Ozimek, L. (1986). Digestibility of amino acids in swine: results and their practical applications. A review. Livestock Production Science 15, 367-388.

Tanksley, T. D. \& Knabe, D. A. (1984). Ileal digestibilities of amino acids in pig feeds and their use in formulating diets. In Recent Advances in Animal Nutrition-1984, pp. 75-95 [W. Haresign and D. J. A. Cole, editors]. London: Butterworths.

Van Barneveld, R. J., Batterham, E. S. \& Norton, B. W. (1991 $a$ ), The effect of dry heat on the total amino acid composition of field peas. Proceedings of the Nutrition Society of Australia 16, 122.

Van Barneveld, R. J., Batterham, E. S. \& Norton, B. W. (1991 b). Utilization of ileal digestible lysine from heattreated field peas by growing pigs. In Manipulating Pig Production $11 I$, p. 184 [E. S. Batterham, editor]. Attwood: Australasian Pig Science Association.

Varnish, S. A. \& Carpenter, K. J. (1975). Mechanisms of heat damage in proteins. 5. The nutritional values of heat-damaged and propionylated proteins as sources of lysine, methionine and tryptophan. British Journal of Nutrition 34, 325-337.

Wiseman, J., Jagger, S., Cole, D. J. A. \& Haresign, W. (1991). The digestion and utilization of amino acids of heattreated fish meal by growing/finishing pigs. Animal Production 53, 215-225. 